\title{
THE MIDDLE WAY
}

The Emergence of Modern Religious Trends in

Nineteenth-Century Judaism 


\section{Studies in ORthodox Judaism}

\section{Series Editor}

Marc B. Shapiro (University of Scranton, Scranton, Pennsylvania)

\section{EDITORIAL BOARD:}

Alan Brill (Seton Hall University, South Orange, New Jersey)

Benjamin Brown (Hebrew University, Jerusalem)

David Ellenson (Hebrew Union College, New York)

Adam S. Ferziger (Bar-llan University, Ramat Gan)

Mirl Freud-Kandel (University of Oxford, Oxford)

Jeffrey Gurock (Yeshiva University, New York)

Shlomo Tikoshinski (Jerusalem)

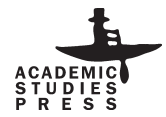




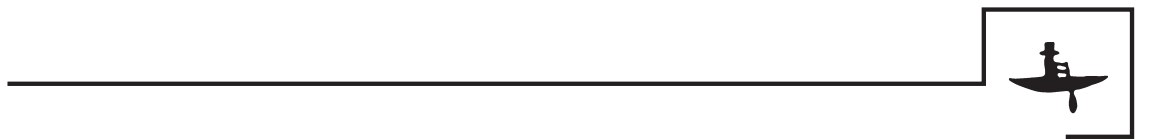

THE MIDDLE WAY

The Emergence of Modern Religious Trends in Nineteenth-Century Judaism

Responses to Modernity in the Philosophy of

Z. H. Chajes, S. R. Hirsch, AND S.D. Luzzatto

VOLUME TWO

EDITOR: Dr. Asael Abelman

TRANSLATOR: Dr. Jeffrey Green 
Library of Congress Cataloging-in-Publication Data:

A catalog record for this title is available from the Library of Congress.

Copyright (C) 2014 Academic Studies Press

All rights reserved

Vol. I:

ISBN 978-1-6181 1-407-5 (hardback)

ISBN 978-1-6181-409-9 (electronic)

Vol. II:

ISBN 978-1-6181 1-408-2 (hardback)

ISBN 978-1-6181-410-5 (electronic)

Cover design by Ivan Grave

On the cover:

"The Return of the Jewish Volunteer from the Wars of Liberation to His Family Still Living According to Old Customs", by Moritz Daniel Oppenheim (1833-34).

Published by Academic Studies Press in 2014.

28 Montfern Avenue

Brighton, MA 02135, USA

press@academicstudiespress.com

www.academicstudiespress.com 
Ephraim Chamiel 